流産を契機として発見された若年者横行結腸癌の 1 例

\author{
獨協医科大学第 1 外科 \\ 根 本 有紀子 小野寺 真 一 橋 本 龍 二 \\ 椿昌裕難 波 美津雄 砂川正勝
}

症例は29歳，女性. 平成12年 9 月に流産したか，その後も持続する下腹部痛を主訴に 近医内科を受㟝，便潜血反応が陽性であったため、当院消化器内科を紹介され大腸内視 鏡検查を受けた、大腸内視鏡検查では肝彎曲部寄りの横行結腸に腸管内腔全体を占める 1 型の腫痬を認め, 同部より口側への内視鏡挿入は不可能でった. 生検の結果, 中分 化腺癌と診断され全身精査後の平成13年 1 月15日に結腸右半切除， 3 群リンパ節郭清術 を施行した。

切除標本にて腫瘍汶 $7 、 5 \times 4 \mathrm{~cm}, 1$ 型, 中分化腺澏, ss, ly $1, v 1, \mathrm{n} 3(+) \mathrm{P}_{0} \mathrm{H}_{0}$ $\mathrm{M}($ (一) stage IIIbであった。術後にCDDP，5-FU，アイソボリンを用いた化学療法を施 行し退院となった。現在再発を認めず経過観察中である。

若年者で，かつ流産後であったが持続する下腹部痛を主訴とした場合，大腸癌をはじ めとする腎性腫璌の可能性を考え精查することの重要性を再認識させられた症例であっ た.

索引用語：流産, 若年者, 結腸癌

緒 言

今回われわれは，流産を契機として持続する下腹部 痛を主訴とし，精查により横行結腸癌と診断され手術 を施行した症例を経験した，症例は今回のエピソード まで自覚症状として排便の異常はなかった。弤娠期の 悪性腫湢発生例は少ないため診断が遅れることがあ り，かつ若年者であることから予後不良例が多いとさ れている. 近年好娠，分婏の高齢化が進み弤娠期の要 性腫場增加も考えられるため若干の文献的考察を加え て報告する。

\section{症例}

症例：29歳, 女性.

主訴：下腹部痛。

既往歴：平成10年 8 月帝王切開にて第一子出産. 平 成12年 9 月妊娠第 10 週に流産。

家族歴：特記すべきことなし。

現病歴: 平成12年 9 月流産後に持続する下腹部痛の

2002年11月 12 日受付 2002 年11月20日採用

〈所属施設住所〉

广321-0093栃木県下都賀郡壬生町大字北小林880
ため，産婦人科を受診するが産婦人科的には異常なし と診断され，疼痛も自制内であったため特別の治療は 行われなかった．11月に入り疼痛の出現頻度が增した ため近医内科を受診した，便潜血反応が 2 回とも陽性 のため, 当院消化器内科を 12 月 5 日紹介受診した。大 腸内視鏡検査で，横行結腸肝繁曲寄りに1 型で腸管の 内腔全体を占める腫啺を認め，生検により Group $5 て$ あった。このため手術目的に当科に12月11日紹介とな った.

入院時現症：腹部は平坦軟。湾上部抽よ゙右側に軽 度の圧痛索認めたが腫瘾は触知せず，表在リンパ節も 触知しなかった，眼瞼，眼球結膜に筫血，黄疸認めな かった.

入院時検查所見：血算,生化学検查に異常を認めず, 腫場マーカーにおいても, CEA, AFP, CA19-9, CA72 ー4いずれも正常範囲内であった。

注腸造影検查：横行結腸肝筫曲よりに, 長径約 $6 \mathrm{~cm}$ 大の apple core sign を認めた（図 1 ).

下部消化管内視鏡検査：横行結腸肝賉曲よりに，易 出血性で八つ頭状の 1 型の腫愓を認めた。腫場は腸管 の内腔全体を占めており、これょり口側への内視鏡の 


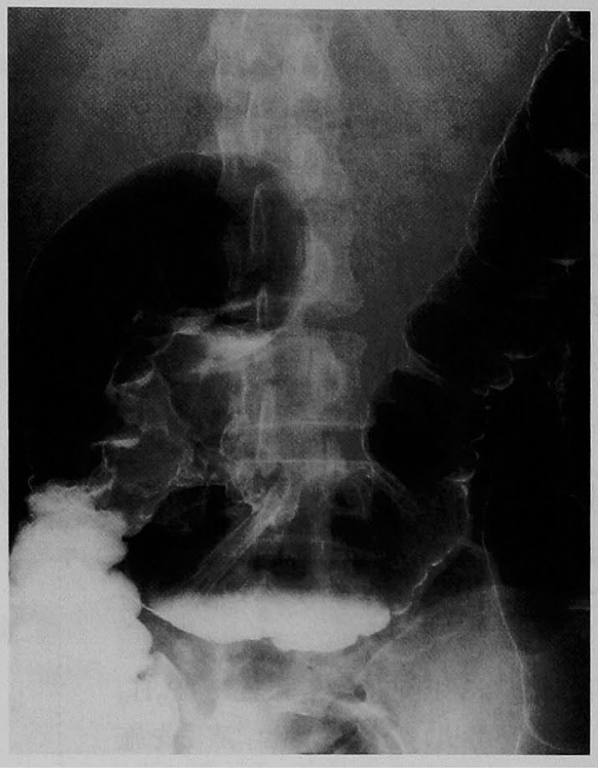

図 1 注腸造影検査：横行結腸肝第曲寄りに, 長 径約 $6 \mathrm{~cm}$ 大の apple core sign を認める.

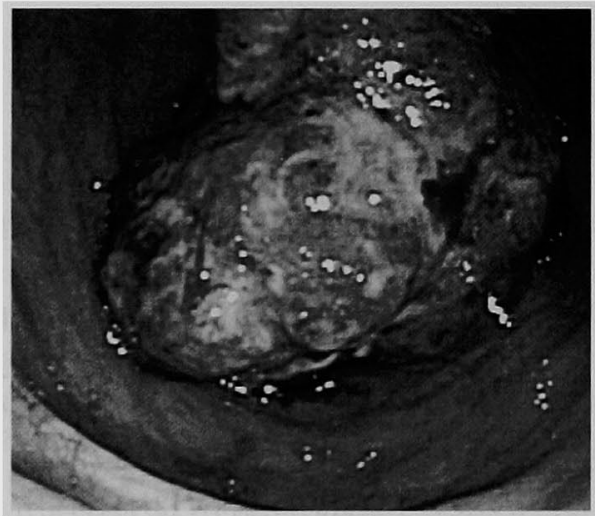

図 2 下部消化管内視鏡検査：横行結腸肝彎曲 寄りに，易出血性て八つ頭状の 1 型の腫癔を認 める.

扦入は不可能であった, 生検では Group 5 (中分化腺 癌)であった（図 2 ).

腹部 CT 検查：右側中腹部に直径約 $5 \mathrm{~cm}$ 大の腫湯 を認めたが、リンパ節腫大, 腹水貯留や肝転移などの 所見は認めなかった(図 3 )。また，胸部X線写真でも 肺転移を思わせる陰影はみられなかった。

以上より横行結晹癌の診断で平成13年 1 月 15 日，結 腸右半切除術, 3 群リンパ節郭清を施行した.

切除標本：腫瘍の大きさは $7 \times 5 \times 4 \mathrm{~cm}, 1$ 型の病

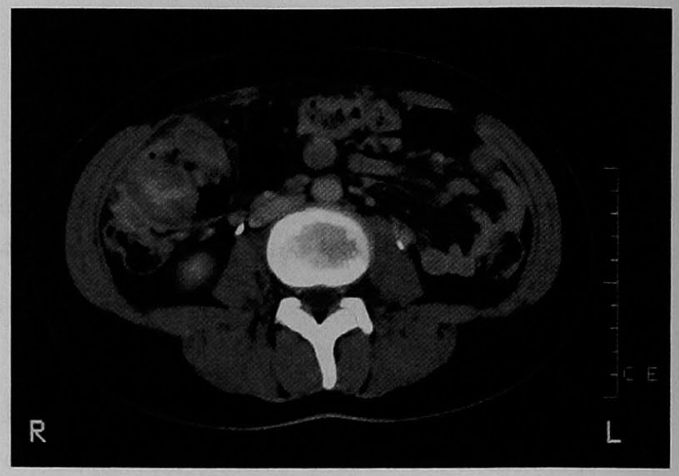

图 3 腹部 CT 検查：右側中腹部に直径約 $5 \mathrm{~cm}$ 大の腫 湟を認める. 腫揚周囲および大動脈周囲リンバ節腫大 などの所見は認められない。

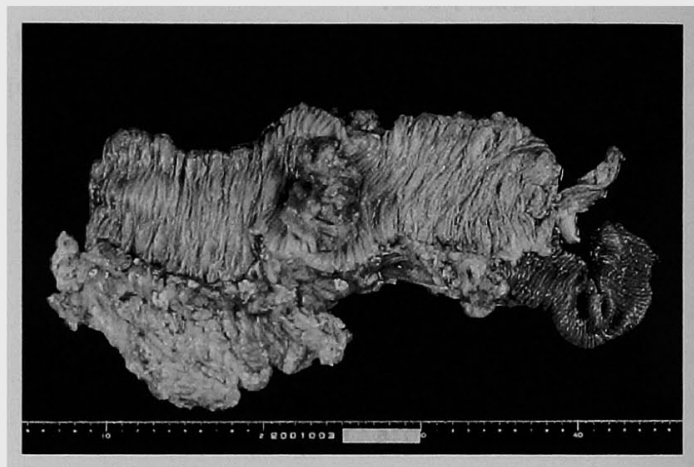

図 4 切除標本：腫場径は $7 \times 5 \times 4 \mathrm{~cm}, 1$ 型の進行癌 である.

変であった（図 4$)$.

病理組織学的所見：中分化腺癌，深達度 Ss，脈管内 侵襲は ly 1 ，v1で，リンパ節転移は 1 群，2 群には認 められなかったが， 3 群の№.223に skip metastasis を 認めた。 以上より ss, n $3(+) \mathrm{P}_{0} \mathrm{H}_{0} \mathrm{M}(-)$ stage IIIb, 根治度 B の診断となった（図 5 )。

術後経過：術後,経過は合併症もなく良好であった。 22病日目から PFL 療法 (CDDP $350 \mathrm{mg} / \mathrm{m}^{2} /$ day, 5$\mathrm{FU} 13 \mathrm{mg} / \mathrm{m}^{2} /$ day, アイソポリン $15 \mathrm{mg} /$ body $/$ day 5 日間静注）による化学療法を施行した。 40病日目に退 院し，その後も外来および入院で化学療法を継続して いる. 現在術後 1 年10力月経て，再発の所見なく経過 観察中である.

\section{考 察}

40歳未満の若年者大腸癌は全大腸癌の $1 \sim 3 \%$ を占 めるとされ ${ }^{1)}$, 非若年者と比較して性差, 占居部位につ いては差を認めないが粘液癌, 低分化癌が多くリンパ 


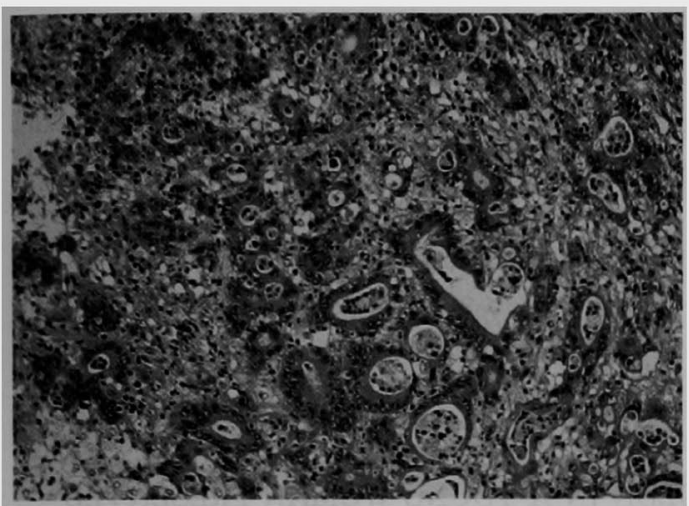

図 5 病理組織（H.E.染色 $\times 100$ 倍）：組織学的には中分 化腺癌であるが一部に粘液癌の病单も認め, 部分的に 炎症性の間質成分を伴っている。

節転移，槳膜浸潤，腹膜播種の陽性率が高く、このた め治臣切除率が低く予後不良であることが特徵とされ ている゙ーい. しかし治瘾切除例の 5 年生存率には有意 差はないとされており3)-5)，若年者大腸癌においては 早期発見と十分なリンパ節郭清や他臟器合併切除によ り積極的に治寉切除をめざすことが重要と思われる. 当科における過去 25 年間での 40 歳末満の若年者結腸癌 症例は13例 $(3.2 \%)$ で, 高分化腺癌が 8 例と多く, 哚 達度は se 以深が 9 例と多く,リンパ節転移陽性は 6 例 であった，非治疮因子として肝転移，腹膜転移，n十 $(+)$ の症例か 4 例で, 術後 1 年から 3 年以内の死亡例 は 6 例であった。

一方奼娠に併存した大腸癌の発生頻度は10万の妊娠 に対し $1 \sim 2$ 例で ${ }^{(6)}$, 予後は不良とされている ${ }^{78)}$.この 原因として若年者であること, 症状が妊娠随伴症状と 類似していること, 妊娠中のX線被爆を恐れて消化器 の精査が十分行われないことなどから早期診断が遅れ ると思われる．自験例も流産後であったことから，初 発症状より診断確定まで約 3 力月を要した。

妊娠の継続は妊娠前半期には癌進展に著明な影響を 与えず, 弤娠後半期には癌進展を促進し, 特に分婏, 産螎を経ると急速に進展するとの報告もある(1111が， 癌の增殖, 転移が加速されるという確証はないとする 報告もある ${ }^{1213)}$

妊娠に併存した消化器癌の治療方針として, 痹の進 行度と妊娠月数により方針を決定する報告が多 (2819) -11). 根治手術が可能な場合，母体の救命を最優先 し, 早急に外科手術を施行すべきで, 通常の癌治療と 同様に進行度に応じた手術, 補助化学療法が原則であ
る.胎児が体外で生存不可能な 20 週以内には奼娠中絶 に引き続き，一期的に外科手術を行う. 胎児が体外で 生存可能な28週以後には母児双方を救命すへく誘導分 婏または帝王切開後に外科手術を行う。根治手術が不 可能な場合には胎児の生存を第一として集学的治療に より母体の QOL を確保する治療を選択する．いずれ にしても精神的ケアも含め患者, 家族とインフォーム ドコンセントを繰り返し, 最善の治療法を選択してい くことが必要となる.

なお, 胎児・胎盤への悪性腫痬の転移はきわめて稀 で, 悪性黒色腫・白血病・悪性リンパ腫でわずかにみ られるのみで, 他の悪性腫場ではほとんどないといっ てもよいとの報告がある(4).

\section{結語}

女性に発生する悪性腫癔の約 $15 \%$ は生殖年路に認め られており ${ }^{15)}$ ，稀とはいえ妊娠中でも癌の発生は起こ りうる．弤娠・分婏年齡の高齢化傾向を考慮すると， 今後癌合併妊娠例の增加が予測される。これを念頭に 置き妊娠期における嘔気, 哣吐, 腹痛, 下痢, 下血な どの症状が継続した場合，母児を考慮しながらも可能 な限り内視鏡検査などの精査を行うことが必要であ る.

なお, 本論文の要旨は第780回外科集談会 (2001年 3 月, 東京)で発表した.

\section{文献}

1）吉井由利，小林世美 : 若年者（30歳未満）の大腸 癌。 日本大腸肛門病会誌 $43: 73-77,1990$

2）加藤友门，森本剛史, 渡辺晃祥他：若年者の直腸 痛. 外科 $40: 802-807,1978$

3）奥野匡有, 池原照幸, 長山让義他：若年者大腸癌 の臨休满理学的唡討. 日消外会誌 $19: 2397-$ 240?, 1986

4）大東諴司，芳賀駿介，加藤博之地：若年者大腸癌 の臨床病理学的検討. 日本大腸肛門病会誌 42 ： 583-587, 1989

5）奥本 聡，堀田芳樹，加藤道男他：若年者大腸癌 の臨床病理学的検討. 日消外会誌 $24: 8318: 9$, 1991

6）山形敉一, 井上修一：姡, 産, 接の偶発合併症. 現代産婦人科学大系 $1 \mathrm{k}$, 中山書店, 東京, 1973

7）矢野浩史, F洲洋, 浜田雄行：妊娠に合併した 大晹癌の 2 症例. 日産婦中国四国会誌 $34: 135-$ 141,1986

8) 北岡久三 : 消化器癌と妊張。外科 $46: 244-24 x$, 
1984

9）中島真太郎，加藤良隆，高橋忠照他：分婏により 発見された若年者直腸癌の 1 例. 交通医 $48: 122$ $-127,1994$

10）石川 隆, 板野 聡, 寺田紀彦他：妊娠に合併し た大腸癌の 1 例。日臨外医会誌 $53: 2186-2189$ ， 1992

11）山形敕一, 宇塚善郎：妊娠と悪性腫瘍の合併一内 科の立場から一。癌の臨 $16: 574-584,1970$
12）佐治文隆：姡娠は腫毫の発生・進展に影響する か? 産授の実際 $46: 773-779,1997$

13）梅咲直彦, 田中哲二, 深山雅人：妊娠中の癌免疫. 産と婦 $5: 575-581 ， 2001$

14) Moore JL, Martin JN : Cancer and pregnancy. Obstet Gynecol Clin North Am 19:815, 1992

15）田中忠夫：姃娠と癌一臨床医はどう対応するか 一. 産婦の実際 $46: 772,1997$

\title{
A CASE OF CANCER OF THE TRANSVERSE COLON IN A YOUNG WOMAN PRESENTED WITH ABORTION
}

\author{
Yukiko NEMOTO, Shin-ichi ONODERA, Ryuji HASHIMOTO, \\ Masahiro TSUBAKI, Mitsuo NANNBA and Masakatsu SUNAGAWA \\ First Department of Surgery, Dokkyo University School of Medicine
}

A 29-year-old woman experienced abortion in September 2000 visited to the patient's internal doctor because of lower abdominal pain persisting after abortion. Her stool guaiac tests were positive, and she was referred to the department of gastrointestinal medicine in our hospital and underwent colonofiberscopic study. The study disclosed a type I tumor occupying the entire lumen of the transverse colon near the hepatic flexure, and it was impossible to insert an endoscope from the site to oral side. As a result of a biopsy, moderately differentiated adenocarcinoma was diagnosed. After systemic exploration, a right hemicolectomy with dissection of group 3 lymph nodes was performed on January 15, 2001. On the resected material, the tumor was $7 \times 5 \times 4 \mathrm{~cm}$ in dimension, type 1 , moderately differentiated adenocarcinoma, ss ly1, v1, $\mathrm{n} 3(+) \mathrm{P}_{0} \mathrm{H}_{0} \mathrm{M}(-)$, and stage IIIb. After chemotherapy with CDDP, $5 \mathrm{FU}$, and isovoline following the operation, the patient was discharged from the hospital. The patient has been free from recurrence at present and is followed in the outpatient's clinic.

This case which involved a young woman after abortion who complained of persistent lower abdominal pain has made us see the importance of conducting close examinations considering possible malignancies including colorectal cancer. 